\title{
HUMAN RIGHTS OF WOMEN AND THE PUBLIC/PRIVATE DIVIDE IN INTERNATIONAL HUMAN RIGHTS LAW
}

\author{
Ivana Radačić*
}

Summary: Women's human rights have long been marginalised in international human rights law. The public/private divide on which international human rights law rests has been constructed in a manner that obscures the experiences of women and fails to challenge women's disadvantage.

In this paper, I discuss the problem of the marginalisation of women's rights in international human rights law and propose reforms to fully incorporate women's experiences of human rights abuse. The focus of the analysis is on the public/private divide and its reflection in the conceptualisation of rights, the doctrine of state responsibility, and the principle of equality.

The main argument of this paper is that the gendered nature of the divide needs to be transcended and the public/private divide re-conceptualised in a manner that challenges discrimination and violence against women in the private sphere, while protecting women's freedom of self-determination and personal development in both the 'public' and the 'private' sphere. Such a re-construction of the public/private divide entails using gender analysis in interpreting rights, state responsibility, and equality.

\section{Introduction}

Women's rights have long been marginalised in international human rights law. Despite the high claims of inclusiveness, of protecting the fundamental rights of all human beings, international human rights law has been under-inclusive of women's experiences of human rights abuse. Interests fundamental for women's wellbeing have traditionally been conceptualised as 'private issues', outside the purview of international human rights law. While recently the public/private divide has started to be re-conceptualised in a manner more responsive to the experiences of women, international human rights law is still gender biased.

This paper analyses the problem of marginalisation of women's rights in international human rights law, explores the reasons for such marginalisation and proposes reforms to fully incorporate women's rights. The first part of the paper introduces the concept of women's rights and discusses their status in international human rights law. The second

\footnotetext{
" Ivana Radačić, LL.M. PhD student and part-time lecturer, University College London.
} 
part of the paper analyses gender biases in international human rights law. The focus is on the public/private divide and its reflection in the conceptualisation of rights, the doctrine of state responsibility and the principle of equality, since its gendered nature has been identified as the main obstacle for the protection of women's rights. The paper finally proposes a re-conceptualisation of international human rights law so as to include violations of the human rights of women and thus become truly universal.

\section{Marginalisation of women's (human) rights in international human rights law}

\subsection{What are women's human rights?}

The terms 'human rights of women,' 'women's human rights' and 'women's rights' have not been clearly defined, and different writers use them in different senses, sometimes interchangeably. ${ }^{1}$ Most use the expression 'women's rights' to define women-specific violations, that is, violations directed against women on the grounds of their sex/gender, ${ }^{2}$ or that affect women disproportionately. The term 'human rights of women' or 'women's human rights' is usually used in a broader sense to define all violations of human rights where the victim is a woman.

Women suffer different types of violations of their human rights. Some appear to be indistinguishable from those suffered by men (eg unlawful arrest and detention based on political activities), though even these violations might be less visible 'because the dominant political actor in our world is male', ${ }^{3}$ or they may impact women differently from men due to their general disempowerment, and different socio-economic circumstances. In other types of violations, sex/gender may determine the forms that violation takes. For example, the torture of a female prisoner very often takes the form of sexual abuse; and the denial of a fair trial to a woman is very often based on gender stereotypes or a misunderstanding of women's experiences. In addition, in many instances of violation of human rights of women, sex/gender is the primary basis of violation. This is the case with gender-specific violence (such as rape, domestic violence,

\footnotetext{
1 Andrew Byrnes 'Feminism and International Human Rights Law- Methodological Myopia, Fundamental Flaws or Meaningful Marginalization? Some Current Issues' (1992) 12 Australian Year Book of International Law 205.

2 The term gender has traditionally been used to describe the socially constructed identity of women and men, while the term sex has traditionally been used to refer to their biological characteristics. However, as noted by many feminists, gender and sex are not easily separable categories. For a critique of the binary view of sex/gender, see, eg, Judith Butler, Gender Trouble: Feminism and Subversive Identity (Routledge, New York 1990).

3 Charlotte Bunch 'Women's Rights as Human Rights: Toward a Re-vision of Human Rights' (1990) 12:4 Human Rights Quarterly 486, 498.
} 
enforced prostitution and trafficking, female genital mutilation), violation of reproductive rights (such as forced abortions or sterilisation) and sex discrimination. Finally, in most types of violations, there is a complex interaction between sex and other constituent elements of identity, such as sexual orientation, race, class, religion, and political affiliation. For example, while a black, lesbian woman, a member of a political minority, might be unlawfully detained for political activities and subjected to harassment in custody due to her sexual orientation and race, she might then be raped in custody, which is a gender-based violation.

These examples show how gender, as it intersects with other identity characteristics, influences the form of human rights abuse and provides an argument for the idea of inclusive jurisprudence which would display understanding of the multiplicity of identities and of the intersectionality of discrimination. ${ }^{4}$ However, dominant interpretations of universality and equality in 'mainstream' international human rights law ${ }^{5}$ ignore the multiplicity of identity and intersectionality of discrimination, which has had exclusionary effects. Many of these examples of the violations of the human rights of women have traditionally been seen as outside the purview of mainstream international human rights law on the basis that they are sex-specific and hence not universal. However, as a 'universal subject' does not exist in reality, in practice it has acquired a male gender (and other more powerful identity characteristics). ${ }^{6}$

\footnotetext{
4 The multiplicity of identities and the intersection of different forms of discrimination have long been discussed by feminists of colour, lesbian feminists, 'Third World' feminists and post-modern feminists. In respect of the intersection of gender and sexual orientation discrimination, see, for example, PA Cane 'Feminist Jurisprudence: Grounding the Theories' (1989-90) 4 Berkley Women's Law Journal 191. In respect of the intersection of racial and gender discrimination, see, for example, Kimberle Crenshaw 'Demarginalizing the Intersection of Race and Sex: A Black Feminist Critique of Antidiscrimination Doctrine, Feminist Theory and Antiracist Politics' (1989) University of Chicago Legal Forum 139. In respect of postcolonial concerns, see, for example, CT Mohanty 'Under Western Eyes: Feminist Scholarship and Colonial Discourse' in CT Mohanty and R Torres (eds), Third World Women and the Politics of Feminism (Indiana University Press, Bloomington 1992) and Ratna Kapur 'Revisioning the Role of Law in Women's Human Rights Struggles' in Saladin Meckled-Garica and Basak Cali (eds), The Legalisation of Human Rights: Multidisciplinary Perspectives, (Routledge, London 2006).

5 By mainstream international human rights, I mean the main non-gender specific human rights instruments and mechanisms which have been given special importance within the international human rights system (the so-called 'Bill of Rights'- UN Declaration of Human Rights; International Covenant on Civil and Political Rights; International Covenant on Economic, Social and Cultural Rights; and the Convention against Torture and Other Cruel, Inhuman or Degrading Treatment or Punishment).

6 Diane Otto 'Disconcerting Masculinities: Reinventing the Gendered Subject(s) of International Human Rights Law' in Doris Buss and Ambreena Manji (eds), International Law: Modern Feminist Approaches, (Hart Publishing, Oxford 2005) 106.
} 


\subsection{Status of women's rights in international human rights law}

In mainstream human rights law there has traditionally been 'relatively little acknowledgement that gender is an important dimension in defining the substantive content of rights [and] ... that a state's obligation to ensure equal enjoyment of a right by women may entail the taking of measures quite different from those which may be necessary to ensure that men enjoy that right'. ${ }^{7}$ Gender inequality has been dealt with only through the non-discrimination provision, conceptualised in a formalistic manner as equal treatment. However, the equal treatment strategy has been impotent in securing the enjoyment of human rights by women, as women suffer forms of human rights violations different from men, on account of both their biological and social difference (primarily in terms of power). Hence, the only way to make women's rights visible was to insist on a separate body of women's rights. ${ }^{8}$ However, women's rights were given lesser status and resources, and weaker enforcement mechanisms. ${ }^{9}$ In addition, even the women-specific instruments have been restricted by the androcentric conceptualisation of equality. ${ }^{10}$

\footnotetext{
7 Byrnes (n 1).

8 The conventions that focus entirely or partially on discrimination against women include: the Convention on the Political Rights of Women; the Convention on the Nationality of Married Women; the Convention on Consent to Marriage, Minimum Age for Marriage and Registration of Marriages; and the Convention on the Elimination of All Forms of Discrimination against Women (CEDAW), which is the most important and most comprehensive convention. Of importance are also conventions of the International Labour Organisation, and the outcomes of the world conference on women (especially the Beijing Declaration and Platform for Action), the Vienna Declaration and Programme for Action, and the ICPD Programme for Action, as well as the UN Declaration on the Elimination of Violence against Women. Finally, it is also important to mention the existence of the relevant thematic rapporteurs (most notably, the Special Rapporteur on violence against women, its causes and consequences, and the Special Rapporteur on trafficking in persons, especially in women and children of the Human Rights Commission) and working groups.

9 For example, it was only in 1999 that the Protocol to CEDAW was adopted, giving the Committee the power to assess individual complaints and to conduct inquiry into gross and systematic abuses of women's rights. Optional Protocol to CEDAW (adopted 6 October 1999, entered into force 22 December 2000) 2131 UNTS 83.

10 Activities of the Commission on the Status of Women, especially in its earlier days, have mostly been aimed at putting women in the same position as men. Even CEDAW, which in many respects represents a significant achievement in the fight for women's rights, adopts an androcentric standard of equality, frequently constraining its language with expressions such as 'equal rights', 'on equal terms with men', and 'on the basis of equality with men' (even in the area of reproductive freedoms), and omitting some gender-specific violations such as violence against women. This has been remedied, however, by the CEDAW Committee, which has been providing a lead in employing a substantive standard of equality and conceptualising gender-specific harms and discrimination as human rights violations. See Hilary Charlesworth and Christine Chinkin, The Boundaries of International Law: A Feminist Analysis (Manchester University Press, Manchester 2001) 216-218.
} 
A dual strategy has therefore failed to secure enjoyment of human rights by women. Not only was the strategy practically problematic in artificially dividing people into two categories, but it was also politically problematic as it implied that women's victimisation was not of universal concern. It has contributed to the conceptualisation of women's rights as different from (universal) human rights, and therefore of a lesser status. Women's rights have been branded as 'particular', while the 'universality' of rights based on male experiences has not been questioned. ${ }^{11}$ Thus, we face a situation that "what is done to women is either too specific to women to be seen as human or too generic to human beings to be seen as specific for women.' ${ }^{12}$

In the 1990s a new strategy emerged that argued that 'women's rights are human rights', and proposed gender mainstreaming as the 'global strategy for promoting gender equality'. ${ }^{13}$ Throughout the 1990s significant advances were made in the institutions, substances and procedures of international human rights law as it is applied to women, mostly as a result of the vigorous activism of women's NGOs. At the 1993 Vienna Conference, it was affirmed that 'human rights of women and of the girl-child are an inalienable, integral and indivisible part of universal human rights'. ${ }^{14}$ The Vienna Conference also firmly put violence against women on the human rights agenda, which pushed the adoption in 1994 of the UN Declaration on the Elimination of Violence against Women ${ }^{15}$ and the institution of the position of the UN Special Rapporteur on violence against women. ${ }^{16}$ Moreover, at the 1994 Cairo Conference on Population and Development, women's sexual and reproductive rights were finally explicitly placed on the human rights agenda. ${ }^{17}$ In addition, the Beijing Declaration and Platform for Action initiated the process of gender main-

\footnotetext{
11 Otto (n 6).

12 CA MacKinnon, 'Rape, Genocide and Women's Human Rights' (1994) 17 Harvard Women's Law Journal 5, 6.

13 Sari Kouvo 'The United Nations and Gender Mainstreaming: Limits and Possibilities' in Doris Buss and Ambreena Manji (eds), International Law: Modern Feminist Approaches, (Hart Publishing, Oxford 2005).

14 'Vienna Declaration and Programme for Action' Third World Conference on Human Rights (12 July 1993) UN Doc A/CONF.157/23.

15 UNGA, 'Declaration on the Elimination of Violence against Women' (20 December 1993) UN Doc A/RES/48/104.

16 See UNCHR Resolution 45 (1994) UN Doc E/CN 4/1994/132. Prior to that, genderbased violence was only mentioned in women's specific instruments. The most important was General Recommendation 19. CEDAW Committee, 'General Recommendation 19' in 'Note by the Secretariat, Compilation of General Comments and General Recommendations Adopted by Human Rights Treaty Bodies' (2004) HRI/GEN/Rev.7, 246.

17 'Programme of Action' International Conference on Population and Development (18 October 1994) UN Doc A/CONF.171/13.
} 
streaming within the UN, which has had some success. ${ }^{18}$ This is exemplified by the adoption of a few gender sensitive general comments by the human rights committees, such as the Human Rights' Committee's (HRC) General Comment 28 on equal rights of men and women (2000), ${ }^{19}$ the Committee on Economic, Social and Cultural Rights' (CESCR) General Comment 16 on the equal right of men and women to the enjoyment of all economic, social and cultural rights (2005), ${ }^{20}$ and the Committee on the Elimination of Racial Discrimination's (CERD Committee) General Comment 25 on gender aspects of discrimination (2000), ${ }^{21}$ and decisions under individual complaints mechanism, such as NL $v$ Peru (2005). ${ }^{22}$

However, the integration of women's rights into the mainstream has not been complete. There is still no binding instrument on violence or reproductive rights at the UN level. Moreover, these issues are still marginalised in international human rights jurisprudence. For example, the Committee against Torture (UNCAT) still neglects gender forms of torture: it has yet to conceptualise sexual violence committed by private individuals, ${ }^{23}$ and violation of reproductive and sexual rights (such as forced

18 'Beijing Declaration and Platform for Action' Fourth World Conference on Women, (15 September 1995) UN Doc. A/CONF.177/20 (1995) and A/CONF.177/20/Add.1 (1995).

19 The comment conceptualises gender discrimination not only as a violation of Article 3 of the Convention (equal rights of men and women), but as a violation of each of the substantive rights guaranteed by the ICCPR. HRC, 'General Comment 28' in 'Note by the Secretariat, Compilation of General Comments and General Recommendations by Human Rights Treaty Bodies' (2004) HRI/GEN/Rev.7, 178.

20 This comment is particularly progressive. It explicitly adopts the substantive notion of equality and embraces the use of affirmative action. The comment conceptualises gender discrimination as violation of substantive rights under the Covenant, giving examples of particular gender specific violations of economic, social and cultural rights. CSECR, 'General Comment 16’ E/C.12/2005/4.

21 The Comment in paragraph 1 states that 'racial discrimination does not always affect women and men equally or in the same way. There are circumstances in which racial discrimination only or primarily affects women, or affects women in a different way, or to a different degree than men.' CERD Committee, 'General Comment 25' in 'Note by the Secretariat, Compilation of General Comments and General Recommendations by Human Rights Treaty Bodies' (2004) HRI/GEN/Rev.7, 217.

22 In NL $v$ Peru a 17-year-old girl who carried an encephalic foetus was denied abortion in circumstances where it was legally available when the health of the pregnant woman was at risk (but criminalised in cases of foetal impairment). HRC found violation of the right to be free from torture, the right to health and the right to privacy. HRC, 'Views on Communication no 1153/2003' (17 November 2005) UN Doc CCPR/C/85/D/1153/2003.

23 For example, in GRB (name withheld) $v$ Sweden, in which a Peruvian woman who had been raped and imprisoned by the Shining Path group argued that she faced torture by both Shining Path and state authorities if she were returned to Peru, UNCAT found the case to be out of the scope of Article 3 since the definition of torture in the Convention did not include rape by a non-governmental entity. On the other hand, in its concluding observation on an Albanian report, UNCAT expressed concern over the prevalence of domestic and sexual violence against women and girls and asked the state to adopt positive measures to prevent, investigate and punish such violence. UNCAT, 'Views on Communication no 226/2003 
abortion and sterilisation, female genital mutilation - FGM, discrimination against women of sexual minorities) as a form of torture. ${ }^{24}$ Similarly, the CERD Committee is still reluctant to advert to gender considerations in its work: it has generally neglected many problems that women in general, and women that belong to ethnic and racial minorities in particular, face, such as racially motivated violence, forced marriages, polygamy, FGM, AIDS/HIV, and employment discrimination. ${ }^{25}$ In addition, despite the ICPD Programme of Action and the landmark HRC decision in $K L v$ Peru which stated that denial of abortion for therapeutic reasons violates the human rights of women, there is still a lot of resistance in accepting sexual and reproductive health and self-determination as human rights. ${ }^{26}$

Finally, still only a small number of cases has been brought by women, and out of these, only a very small number concerns gender-specific human rights abuses. For example, out of 151 individual complaints that UNCAT considered up until 1 May 2005, only 18 were submitted by a woman (out of which two were submitted on behalf of their brothers), and 10 together by a husband and a wife. ${ }^{27}$ Out of 18 cases submitted by women, 5 concerned, inter alia, gender-specific abuses, such as rape, ${ }^{28}$ one concerned the threat of the death penalty as a punishment for 'adultery'29 and one was related to the fear of persecution for involvement in

(GRB v Sweden)' (15 May 1998) UN Doc CAT/C/20/D/83/1997; UNCAT, 'Conclusions and Recommendations: Albania' (21 June 2005) UN Doc CAT/C/CR/34/ALB.

24 UNCAT's approach might be changing, at least in respect of abortion policies. For example, recently, in examining Chile's periodic report, UNCAT expressed concern about practices of denying urgent medical care to women suffering complications from illegal abortions, unless they confess to illegal abortion and provide information on performers. UNCAT, 'Conclusions and Recommendations: Chile' (14 June 2004) UN Doc CAT/C/CR/32/5.

25 Center for Reproductive Rights, Bringing Rights to Bear: An Analysis of the Work of UN Treaty Monitoring Bodies on Reproductive and Sexual Rights (Centre for Reproductive Rights, New York 2002).

${ }^{26}$ For example, at the $49^{\text {th }}$ session of the Commission on the Status of Women, Beijing plus 10, where I was present on behalf of the Croatian Women's Network, the US delegates were insisting for the whole first week that the Beijing Platform for Action should be amended to state that it does not include a 'right to abortion' or any 'new international human right'. Due to a huge amount of opposition, the US finally dropped the proposal, stating that the essence of its proposal was anyhow included in the Beijing Platform.

27 For the jurisprudence of UNCAT, see <http://www.unhchr.ch/tbs/doc.nsf>

28 See UNCAT, 'Views on Communication no 226/2003 (TA $v$ Sweden)' (27 May 2005) UN Doc CAT/C/34/D/226/2003; 'Views on Communication no 146/1999 (ETB v Denmark)' (25 May 2002) CAT/C/28/D/146/1999; 'Views on Communication no 83/1997 (GRB (name withheld) $v$ Sweden)' (15 May 1998) CAT/C/20/D/83/1997; 'Views on Communication no 41/1996 (Pauline Muzonzo Paku Kisoki $v$ Sweden)' (8 May 1996) CAT/C/16/D/41/1996; 'Views on Communication no 143/1999 (SC (name withheld) $v$ Denmark)' (3 September 2000) CAT/C/24/D/143/1999.

29 UNCAT, 'Views on Communication No 149/1999 (AS (name withheld) $v$ Sweden)' UN Doc $\mathrm{CAT} / \mathrm{C} / 25 / \mathrm{D} / 149 / 1999$. 
the promotion of women's rights. ${ }^{30}$ Until now there has been only one case on domestic violence, and it was adjudicated before a women-specific body: AT $v$ Hungary. ${ }^{31}$

This discussion of the status of women's rights in international human rights law shows that while certain advances have been made, gender mainstreaming has not transformed the system. International human rights law is still gender biased. One of the main problems is that gender mainstreaming has mostly been concerned with the integration of gender concerns into the pre-existing framework of international human rights law, rather than transforming the framework itself. ${ }^{32}$ However, 'adding women' (and stirring) cannot secure inclusiveness of international human rights law. Moreover, it may be dangerous in depoliticising discrimination against women and precluding further action, as it might be assumed that 'adding' women is all that is needed for women's equality to be achieved. International human rights law, therefore, needs to be re-conceptualised to include the concerns, values and ethics associated with women. Gender biases must be challenged.

\section{Gender biases in international human rights law: the gendered nature of the public/private divide}

Feminists have identified the gendered nature of the public/private divide as the main obstacle in the protection of women's rights. ${ }^{33}$ The public/private division is the central concept of international human rights law, which appears at many levels. The first level is the question of what should properly come under the purview of international supervision (ie, what should be 'public'), and what should stay solely within the state's sovereign powers (ie, what should be 'private'); in other words, what interests should be defined as human rights. This has been answered in a gendered manner. Reproductive health and self-determination have only

30 UNCAT, 'Views on, Communication No 143/1999 (SC (name withheld) $v$ Denmark)' (3 September 2000) CAT/C/24/D/143/1999.

31 CEDAW Committee, 'Views on the Communication no. 2/2003 (AT v Hungary)' (26 January 2005).

32 For a distinction between integrative and transformative approaches see Kuovo (n 13), citing F Beveredge and S Nott, 'Mainstreaming, A Case for Optimism and Cynics' (2002) 10 Feminist Legal Studies 299, 308.

33 Hilary Charlesworth, Christine Chinkin and Shelly Wright, 'Feminist Approaches to International Law' (1991) 85 American Journal of International Law 615; Celina Romany 'State Responsibility Goes Private: A Feminist Critique of the Public/Private Distinction in International Human Rights Law' in Rebecca Cook (ed) Human Rights of Women: National and International Perspectives (University of Pennsylvania Press, Philadelphia 1994); Karen Engle, 'International Human Rights and Feminism: When Discourses Meet' (1991-92) 13 Michigan Journal of International Law 17; Donna Sullivan, 'The Public/Private Distinction in International Human Rights Law' in Julie Peters and Andrea Wolper (eds) Women's Rights, Human Rights: International Feminist Perspectives (Routledge, New York 1995). 
recently started to be defined as human rights, and states are still given wide discretion in this area.

The second level is the question whether relationships between individuals should fall under the human rights framework. This has also been answered in a gendered manner. Traditionally, only the relationship between individuals and the state - the 'public sphere' - has come within the boundaries of human rights law, while the regulation of the 'private' spheres of family and the relationship between individuals (both in intimate and economic spheres) was left within the states' discretion. International human rights law is still to a large extent focused on the 'public' sphere. This can be seen in the dominant conceptualisation of human rights, the doctrine of state responsibility, and equality.

\subsection{Conceptualisation of rights in international human rights law}

\subsubsection{First-generation rights}

The public/private divide is most visible in first-generation rights, which are still given primacy in international human rights practice. Despite the rhetoric of the 'indivisibility and interdependence of human rights,' affirmed, inter alia, at the 1993 Vienna Conference, international human rights practice still gives the greatest attention to civil and political rights at the expense of addressing social and economic conditions which affect the ability to enjoy these rights. However, neglect of structural social, political and economic inequalities - from which women suffer the most - means that the primacy given to civil and political rights might have adverse consequences for women (and other economically and socially disadvantaged groups). ${ }^{34}$ This is even more the case given that civil and political rights have traditionally been conceptualised in a gendered (male) manner.

Political and civil rights have predominantly been defined as rights aimed at safeguarding individuals from direct governmental interference in personal and political freedoms. Underlying the traditional conceptualisation of these rights is the idea of a pre-social rational agent whose autonomy needs to be protected from direct state interference. This, however, is a false and a gendered view of humans, which does not take into account the relational nature of humans and the impact of human relationships on the development of autonomy. Such a view does not include reproductive rights and freedom from violence in the private sphere as a part of civil and political rights.

${ }^{34}$ Byrnes (n 1); Barbara Stark, 'The "Other" Half of the International Bill of Rights as a Postmodern Feminist Text' in DG Dallmayer (ed), Reconceiving Reality: Women's Perspectives on International Law (American Society of International Law, Washington DC 1993). 
Indeed, these rights have not traditionally been conceptualised as civil and political rights. For example, in the HRC's early general comments on the right to life, on torture, on the right to liberty and security of persons and on privacy, there is no discussion of the specific risks that women face in enjoying these rights, such as restrictions on reproductive and sexual freedoms, violence, and harmful traditional practices. ${ }^{35}$ While women-specific violations of civil and political rights suffered most frequently at the hands of private individuals have started to be acknowledged, ${ }^{36}$ mainstream international human rights law still gives prominence to classical abuses of civil and political rights by state agents.

The right to life - the most important of all human rights - is still primarily concerned with the arbitrary deprivation of life through state action. ${ }^{37}$ Only recently have human rights bodies started to discuss the denial of reproductive self-determination as a threat to a woman's life..$^{38}$ Similarly, the traditional interpretation, in particular by UNCAT, of the right to be free from torture, inhuman and degrading treatment and punishment largely excludes domestic and sexual violence committed against women by private individuals, or violations of their reproductive rights. In addition, the dominant interpretation of the rights to liberty and security of persons and the right of freedom of movement does not address violation of reproductive rights or the fear of violence or situations in which women are held captive by their husbands or relatives. ${ }^{39}$

In addition, even though women's rights are most often violated within the family, the right to respect for family and private life has historically been interpreted as the duty of 'non-interference' in the private and family sphere. The question has often been framed not as whether the right to privacy (in terms of self-determination) has been respected (regardless of the implicated sphere), but rather whether there has been 'governmental interference' in the family sphere. Eisler has argued that, this way, "while ostensibly protecting the right to privacy ...the conventional use of distinction has served as a means of preventing the application and development of human rights standards in relationships between men and women. ${ }^{40}$ The idea of 'non-interference' in the private and

\footnotetext{
35 HRC, 'General Comments nos 6, 8, 16' in 'Note by the Secretariat, Compilation of General Comments and General Recommendations by Human Rights Treaty Bodies' (2004) HRI/GEN/Rev.7,

36 See HRC, 'General Comment no 28' (n 19).

37 Charlesworth and Chinkin (n 10) 234.

38 Rhonda Copelon and others, 'Human Rights Begin at Birth: International Law and the Claim of Foetal Rights' (2005) 13 Reproductive Health Matters 120.

39 Charlesworth and Chinkin (n 10).

40 Riane Eisler, 'Human Rights: Towards an Integrated Theory' (1987) 9 Human Rights Quarterly 287.
} 
family sphere has been attacked by many feminists who have shown that the deliberate policy of selective 'non-interference' is not politically neutral, thus exposing the falsity of interference/non-interference myths. ${ }^{41}$ When the state 'does not interfere' in a family context where a man is battering his wife and children, the state is actually accepting, if not encouraging, the family norms whereby it is allowed for a husband to beat his wife and children, and is hence interfering in or regulating family and gender relations. The state continuously affects the family by influencing the distribution of power between individuals.

Moreover, not all forms of families have been protected from governmental interference by international human rights law. As Sullivan notes, race, class, ethnicity and sexual orientation all shape the definitions of what constitutes a family entitled to protection against state intervention. ${ }^{42}$ While there is a trend in international human rights law to recognise and protect the diversity of family forms and intimate relationships, and the forms of sexual and gender expression, ${ }^{43}$ the heterosexual married couple is still the focus of international protection of family life. ${ }^{44}$ International human rights law still imposes certain conditions for the recognition and protection of unorthodox families (such as cohabitation, or stability or commitment in respect of non-married couples), ${ }^{45}$ and sanctions national prohibitions of certain family and private relations (such as the prohibition of adoption by homosexuals, ${ }^{46}$ or the prohibition of gay marriages) and the non-availability of certain procedures that affect family and private life (such as the non-availability of divorce). ${ }^{47}$ States are given wide discretion in this area.

The right to freedom of religion and the freedom of expression have similarly often been interpreted in a manner that obscures the different forms of oppression of women. On the one hand, the long-held principle of non-interference in the freedom of religion, as a private sphere, has

41 Susan Okin, Gender, Justice and the Family (Harper Collins, Toronto 1989); FA Olsen, 'The Myth of State Intervention in the Family,' (1985) 18 University of Michigan Journal of Law Reform 835; FA Olsen 'The Family and the Market: A Study of Ideology and Legal Framework,' (1983) 96 Harvard Law Review 1497.

42 Sullivan (n 33).

43 Alison Diduck, 'Shifting Familiarity', (2005) 58 Current Legal Problems 235.

44 Diane Otto, 'A Post-Beijing Reflection on the Limitation and Potential of Human Rights Discourse for Women' in DM Koening and KD Askin, War Crimes against Women: Prosecution in International War Crimes Tribunal (Martinus Njihoff Publishers, The Hague, 1999).

45 See, for example, ECtHR, Kroon and Others $v$ Netherlands (App no 18535/91) (1994) Series A no 297-C.

46 See ECtHR, Frette $v$ France (App no 36515/97) ECHR 2002-I.

47 See ECtHR, Johnson and Others $v$ Ireland (App no 9697/82) (1986) Series A no 112. As Ireland has now recognised the right to divorce (being the last member state to do so), this case is now only of historical significance. 
meant sanctioning restrictions of women's sexual, reproductive and other freedoms in the name of religious customs and doctrines. On the other hand, recent endorsement of the state's interference with the freedom of religion in the form of prohibitions on wearing the Islamic headscarf even by adult women, on the grounds of gender equality, is also problematic. They further deny women agency, and restrict women's already restricted choices. ${ }^{48}$

The most controversial issue in relation to the freedom of expression, which has exposed divisions within the feminist community, has been the issue of pornography. ${ }^{49}$ The right has been interpreted in some national contexts as the right to make, distribute and use pornography. ${ }^{50}$ International human rights law has been silent on the issue of adult pornography: adult pornography is not explicitly excluded from the scope of the freedom of expression. Hence, as a form of 'expression' it is subject to the balancing test. ${ }^{51}$ However, it has generally not been recognised that (some forms of) pornography has harmful effects on women's equality and freedom (including from gender-based violence). Pornography has generally been seen as a 'public morality' issue, rather than as a gender equality issue.

\subsubsection{Second-generation rights}

Women's experiences are also marginalised in the dominant interpretation of social, economic and cultural rights. While these rights challenge the dichotomy between positive and negative freedom, which has a greater potential for inclusiveness, they also embody the public/private distinction in a gendered manner. The definition of these rights in the International Covenant on Economic, Social and Cultural Rights (IESCR) indicates the tenacity of the public/private divide. ${ }^{52}$ The ICESCR is largely focused on the 'public sphere'. For example, the definition of the right to just and favourable conditions of work in Article 7 of the ICESCR is confined to work in the public sphere (work for remuneration), excluding

\footnotetext{
48 See ECtHR, Leyla Sahin v Turkey (App no 44774/98) [GC] ECHR 2005-.

49 See Martha Chamallas Introduction to Feminist Legal Theory (Aspen Law and Business, New York 1999).

50 CA MacKinnon, 'Pornography as Sex Inequality' in Women's Lives, Men's Laws (Harvard University Press, Cambridge Massachusetts 2005); CA MacKinnon, 'Pornography's Empire' in Are Women Human? And Other International Dialogues (Harvard University Press, Cambridge Massachusetts, 2006).

51 Freedom of expression is a qualified right, subject to certain limitations. Interference with this freedom will not constitute human rights violation if it is based in law and necessary in democratic society, that is, if it pursues a legitimate aim and if there is a reasonable relationship of proportionality between the means and the aim.

52 International Covenant on Economic, Social and Cultural Rights (adopted 16 December 1966, entered into force 3 January 1976) 993 UNTS 3.
} 
much of the work done by women in the informal economy. Moreover, its language of 'equal pay for equal work' is not very helpful for women, even in the context of the paid, public sector, as the sexual division of work that clusters many women in low-paying jobs 'suitable' for women means that there is often no male comparator. ${ }^{53}$

Another example of neglect of the gender perspective is the right to health, defined in Article 12, which does not address reproductive and sexual health, despite the widespread problem of restrictions on women's reproductive and sexual freedoms, which have serious consequences on women's health and wellbeing. ${ }^{54}$ On the other hand, cultural rights are often used to justify the subordination of women. Indeed, as Rao points out, no social group has suffered greater violations of its human rights in the name of culture than women. ${ }^{55}$

\subsubsection{Third-generation rights}

Third-generation rights, collective rights, might seem at first sight to be of particular promise to women, since they challenge the idea of the individual as an atomistic pre-social person. However, these rights also reflect the gendered (and ethnocentric) private/public divide. This can be seen in the examples of the right to development and the right to self-determination. Thus, the Declaration on the Right to Development (1986) does not contain any reference to women, even though gender discrimination constitutes one of the major impediments to development. In addition, the Declaration's model of development is based on the ideal of the market economy, with the effect that all unpaid work in the home or community, in which most women in the South are engaged, is thus characterised as 'unproductive'. ${ }^{56}$

Similarly, the right to self-determination, allowing 'all peoples' to 'freely determine their political status and freely pursue their economic, social and cultural development ${ }^{\prime 57}$ does not include the right to self-determination of women within the community. ${ }^{58}$ The right has been invoked, and supported, in a number of contexts that allow the oppression

\footnotetext{
53 See, however, CESCR, 'General Comment no 16' (n 20).

54 Despite this exclusion, the Committee has interpreted the right to health to include reproductive and sexual health. See Center for Reproductive Rights (n 25).

55 Areti Rao, 'The Politics of Gender and Culture in International Human Rights Discourse' in Julie Peters and Andrea Wolper (eds.) Women's Rights, Human Rights: International Feminist Perspectives, (Routledge, New York 1995).

56 Charlesworth and Chinkin (n 10).

57 International Covenant on Civil and Political Rights (adopted 16 December 1966, entered into force 23 March 1976) 999 UNTS 171, Article 1(1).

58 Charlesworth, Chinkin and Wright (n 33).
} 
of women. The international community rarely discusses the position of women within a society aspiring to nationhood when determining its response to claims of self-determination. ${ }^{59}$

The above discussion shows that the neglect of women's concerns is still present in the interpretation of the substantive rights of all generations. The interests fundamental for women's wellbeing are still conceptualised as private matters, within the competence of the state. State responsibility for the violations of women's rights is still not fully acknowledged. But 'state responsibility is central to the expansive interpretation of human rights law that seeks to encompass human rights of women. ${ }^{60}$

\subsection{Doctrine of state responsibility}

The doctrine of state responsibility expounds the norms and principles of state responsibility for an international wrongful act, ie a conduct consisting of an act or omission that breaches the international obligation of the state and that can be attributed to the state. ${ }^{61}$ The issue of state responsibility engages two sets of rules: primary rules which define the content and scope of the state's international obligations; and secondary rules which define the conditions under which the state will be considered responsible for the wrongful acts and omissions (when wrongful conduct will be attributable to the state) and the consequences that flow therefrom. ${ }^{62}$ While originally the doctrine was focused on direct state action in the public sphere, in accordance with the idea of non-interference, the doctrine has witnessed considerable expansion and reinterpretation in light of the conditions of modern life where state agents are no longer the sole or primary source of violations of human rights. In this respect, the doctrine has witnessed a considerable shift of the public/ private boundaries. However, feminists have claimed that even the 'new boundaries' are in many aspects closed for women. ${ }^{63}$ The problem is that the doctrine of state responsibility is still not adequately interpreted in a manner to acknowledge the systematic and structural nature of gen-

\footnotetext{
59 Ibid.

60 Romany (n 33).

61 ILC, 'Report of the International Law Commission on the Work of its 53rd Session' (23 April - 1 June and 2 July - 10 August) UN Doc A/56/10, chapter IV: State Responsibility (Draft Articles and Commentary).

62 In other words, primary rules answer the question what obligations the state has, while secondary rules answer the question about when the state will be considered responsible and what the consequences of finding responsibility will be. These, of course, are interrelated questions. Ibid para 77, 59-63.

63 Romany (n 33); Rebecca Cook, 'Accountability in International Law for Violations of Women's Rights by Non-State Actors' in DA Dallmeyer (ed.) Reconceiving Reality: Women's Perspectives on International Law (American Society of International Law, Washington DC 1993).
} 
der discrimination and the role that states play in maintaining gender discrimination. This has serious consequences for the protection of the human rights of women.

\subsubsection{Bases of state responsibility - the norms of attribution}

The secondary rules of state responsibility have originally focused only on the conduct of the state agents. ${ }^{64}$ Only in limited circumstances has the conduct of non-state actors been conceived as attributable to the states - when the state was complicit in the conduct of the non-state actor or in cases where the state subsequently adopted the conduct of the state actor as its own. ${ }^{65}$ However, the doctrine has gradually been expanded to include not only state agency, adoption/ratification and complicity, but also the failure to exercise 'due diligence' in preventing, investigating, punishing and remedying violations by non-state actors, as the bases for state responsibility. ${ }^{66}$ Under the due diligence theory, the state has a duty to 'take reasonable steps to prevent human rights violations and to use the means at the state's disposal to carry out a serious investigation of violations committed within its jurisdiction, to identify those responsible, to impose the appropriate punishment and to ensure the victim adequate compensation. ${ }^{67}$

However, the 'due diligence' principle has not yet been fully accepted by all human rights bodies. For example, UNCAT has not accepted this theory of responsibility due to the Convention's definition of torture, which requires the act to be committed "by or at the instigation of or with the consent or acquiescence of a public official or other person acting in an official capacity. ${ }^{68}$ Moreover, UNCAT has also failed to make a connection between the high prevalence of domestic violence and state acquiescence to torture and inhuman and degrading treatment, even though so many academics and activists had made a case for it, including the former Special Rapporteur on Violence against Women. ${ }^{69}$

${ }^{64}$ For the persons who count as state agents under international law of state responsibility, see Chapter I of Draft Articles with Commentary (n 61) 63-80.

65 Ibid.

66 For the differences between complicity, ratification/adoption and lack of due diligence as bases for state responsibility, see ICL Commentary to the Draft Articles (ibid). The doctrine of 'due diligence' was first expounded in international human rights jurisprudence by the Inter-American Court of Human Rights in Velasquez Rodriguez $v$ Hondouras, and has subsequently been adopted by other international human rights bodies. I-Am Ct HR Velasquez Rodriguez $v$ Hondouras (Ser C) No 4 (1988).

67 Ibid, para 174.

68 Convention against Torture and Other Cruel, Inhuman or Degrading Treatment or Punishment (adopted 10 December 1984 UNGA Res 39/46) Art 1(1).

69 Rhonda Copelon, 'Intimate Terror: Understanding Domestic Violence as Torture' in Rebecca Cook (ed) Human Rights of Women: National and International Perspectives (University 
As discussed by Amnesty International, the responsibility of states for acts which impair the rights of women is sometimes mistakenly perceived to apply only when state agents or officials are the actual perpetrators of the acts. ${ }^{70}$ Moreover, complicity, acquiescence and failure to exercise due diligence are often interpreted too narrowly. States have rarely been found complicit in the system of gender discrimination and violence against women in the absence of clear support or the acquiescence of the state agents to these acts by private individuals in each particular case. ${ }^{71}$ The general context of the pervasive nature of violence against women and gender discrimination, which points to its toleration by the state, has usually not been taken into account when determining the responsibility of the state. States have not been held responsible for maintaining the social and legal system in which violence and gender discrimination is endemic. However, without such contextualisation, the right to be free from violence and the right to be free from discrimination are empty promises.

\subsubsection{Content of state obligations}

Human rights treaties generally do not define in detail the content of all state obligations. The level of detail varies between different treaties. The most detailed provisions on state obligations are provided in two women-specific conventions: the Protocol to the African Charter on Human and People's Rights on the Rights of Women in Africa (African Protocol on Women's Rights) ${ }^{72}$ and the Inter-American Convention on the Prevention, Punishment and Eradication of Violence against Women (Inter-American Convention on Violence against Women). ${ }^{73}$ At the UN level, the non-discrimination treaties (Convention on Eliminating All Forms of

of Pennsylvania Press, Philadelphia 1994); Rebecca Cook 'State Accountability under the Convention on the Elimination of All Forms of Discrimination against Women,' in Rebecca Cook (ed) Human Rights of Women: National and International Perspectives; Rebecca Cook, 'State Responsibility for Violations of Women's Human Rights' (1994) 7 Harvard Human Rights Journal 125; Celina Romany (n 33); UNCHR, 'Report of the Special Rapporteur on Violence against Women, its Causes and Consequences' (6 February 1996) UN Doc E/ CN.4/1996/53.

70 Amnesty International 'Respect, protect, fulfil - Women's human rights: State responsibility for abuses by "non-state actors" AI Index: IOR 50/001/2000.

71 Rebecca Cook, 'State Accountability under the Convention on the Elimination of All Forms of Discrimination against Women,' in Rebecca Cook (ed) Human Rights of Women: National and International Perspectives; 'State Responsibility for Violations of Women's Human Rights' 7 Harvard Human Rights Journal (1994) 125.

72 African Protocol on Women's Rights (adopted 13 September, 2000, entered into force 25 November 2005); CAB/LEG/66.6 Reprinted in 1 Afr Hum Rts LJ 40.

73 Inter-American Convention on Violence against Women (signed 9 June 1994, entered into force 5 March 1995) 33 ILM 1534 (1994). 
Racial Discrimination - CERD, and the Convention on Eliminating All Forms of Discrimination against Women - CEDAW) have more detailed provisions on state obligations than general treaties. ${ }^{74}$

The general rules on state obligations are found in 'general undertaking provisions', where the wording usually includes the obligation to 'respect and ensure' rights and to 'undertake all necessary measures to give effect to rights' contained in conventions without discrimination on any prohibited grounds. This language has been interpreted as including not only negative obligations - obligations to refrain from violating rights, but also positive obligations - obligations to take positive steps to ensure that rights are protected, even in the sphere of relations between individuals. Treaties generally do not enumerate all the measures, but give only some examples. Further guidance is provided by treaty-monitoring bodies/courts in general comments on the 'general undertakings clause' and specific articles, the concluding observations to state parties' reports, and the case law.

It is primarily for the state to assess what is appropriate in the circumstances of its cultural and socio-economic environment. However, the measures have to be appropriate and effective, and capable of achieving the results that the states have committed themselves to through the international instrument. The ultimate determination as to whether all appropriate measures have been taken is made by the treaty-monitoring body/court. The measures are not limited to legal and judicial and administrative measures, ${ }^{75}$ but include educative and other appropriate measures ${ }^{76}$ including social ${ }^{77}$ and cultural ones. ${ }^{78}$ The duties also include the obligations to ensure that individuals are protected from violations of human rights committed by private persons or entities. This requires the states to exercise due diligence to prevent, punish, investigate or redress the harm caused by acts by private persons or entities. The duty to prevent includes 'all those means of a legal, political, administrative and

\footnotetext{
74 International Convention on the Elimination of All Forms of Racial Discrimination (adopted 21 December 1965 UNGA Res 2106 (XX)); International Convention on the Elimination of All Forms of Discrimination against Women (adopted 18 December 1979 UNGA Res 34/180).

75 CESCR has explicitly stated that the adoption of legislative measures, as specifically foreseen by the Covenant, is by no means exhaustive of the obligations of states parties. CESCR 'General Comment no 3' in 'Note by the Secretariat, Compilation of General Comments and General Recommendations by Human Rights Treaty Bodies' (2004) HRI/GEN/ Rev.7, 15.

76 HRC, 'General Comment 31' in 'Note by the Secretariat, Compilation of General Comments and General Recommendations by Human Rights Treaty Bodies' (2004) HRI/GEN/ Rev.7,192.

77 CESCR, 'General Comment 3' (n 75).

78 CEDAW (n 74) Art 3.
} 
cultural nature that promote the protection of human rights and ensure that any violations are considered and treated as illegal acts... ${ }^{79}$

However, determining what constitutes positive obligations and the failure of due diligence is not always done in a gender-sensitive manner. Despite the wide-ranging measures foreseen by the general comments of the UN treaty-monitoring bodies, the focus is usually on legislative measures, especially in individual cases. In addition, states are sometimes given wide discretion in implementing the obligations which precludes the proper assessment of the appropriateness of the undertaken measures. ${ }^{80}$ The discretion is particularly wide in 'difficult cases' where consensus on the issue has not yet been established, or where the issue touches upon the sphere of 'morality' or other 'private' spheres which states claim should be within their domestic jurisdiction. This is often the case with the human rights of women (in particular, reproductive and sexual rights).

Finally, there is still a lack of recognition that measures needed to secure the enjoyment of human rights by women may be different from those required to secure the enjoyment of human rights by men. ${ }^{81}$ The need to undertake measures that reflect women's experiences and status are often confused with 'temporary special measures'. However, as the CEDAW Committee has stated in its General Recommendation 25 on special temporary measures:

Not all measures that potentially are, or will be, favourable to women are temporary special measures. The provision of general conditions in order to guarantee the civil, political, economic, social and cultural rights of women and the girl child, designed to ensure for them a life of dignity and non-discrimination, cannot be called temporary special measures. ${ }^{82}$

The problem with the temporary special measures is that the universal international human rights framework considers them exceptional, temporary, aimed only at rectifying past discrimination. Hence, there is relative silence over special measures in international human rights law. They are explicitly foreseen only in 'special' human rights instruments

79 Velasquez Rodriguez (n 66) paras 174-175.

80 The concept of state's discretion is named the doctrine of the margin of appreciation in the ECtHR. Other human rights bodies have also adopted it, though they do not use the term 'margin'.

81 Exceptions are the HRC and CESCR comments on the equal rights of men and women (n 19 and $n$ 20).

82 CEDAW Committee 'General Recommendation no 25' in 'Note by the Secretariat, Compilation of General Comments and General Recommendations by Human Rights Treaty Bodies' (2004) HRI/GEN/Rev.7, 285 paras 18-19. 
which are aimed at eradicating discrimination - the African Protocol on Women's Rights, CEDAW and CERD. ${ }^{83}$ Only the African Protocol on Women's Rights mandates them (in certain circumstances), ${ }^{84}$ while CEDAW and CERD just clarify that they will not be considered discriminatory. ${ }^{85}$ This brings us to the conceptualisation of the principle of gender equality in international human rights law, to which I shall now turn.

\subsection{The principle of equality and non-discrimination}

The right to equality and non-discrimination (inter alia on the basis of sex) has been recognised as a fundamental human right since the beginning of the international human rights movement. ${ }^{86}$ Thus, one of the aims of the UN is 'to promote and encourage respect for human rights and fundamental freedoms for all without distinction as to race, sex, language or religion'. ${ }^{87}$ All major international human rights documents contain a non-discrimination provision, while some international documents, such as CERD and CEDAW, are aimed specifically at eliminating discrimination of historically disadvantaged groups. Still others, such as the African Protocol on Women's Rights and the Inter-American Convention on Violence against Women, are aimed at achieving substantive gender equality, being focused at rectifying the violations of human rights that women suffer.

The non-discrimination norms differ significantly from one to another international human rights instrument. Some instruments, such as the Convention on the Rights of the Child - CRC and the American Convention on Human Rights, contain only a subordinate non-discrimi-

83 Both HRC and CESCPR have declared, though, that state obligations may include positive discrimination against historically disadvantaged groups. See HRC 'General Comment no 18, no 28, no 31' and CESCR, 'General Comment no 16' in 'Note by the Secretariat, Compilation of General Comments and General Recommendations by Human Rights Treaty Bodies' (2004) HRI/GEN/Rev.7.

84 Article 2(1)(d) states that states 'shall take corrective and positive action in those areas where discrimination against women in law and in fact continues to exist' African Protocol on Women's Rights (n 72).

85 The CEDAW Committee has, however, adopted two general recommendations on the subject. General Recommendation 25 firmly encourages states to use 'special measures' as a strategy to achieve de facto, substantive equality. This lead should be followed by other human rights bodies, as suggested by CEDAW. CEDAW, 'General Recommendation 25' (n 82).

86 See for example the $5^{\text {th }}$ preambular paragraph of the Universal Declaration on Human Rights (UDHR) and the $3^{\text {rd }}$ preambular paragraph of ICCPR and IESCR. UDHR (adopted 10 December 1948) UNGA Res 217 A(III); ICCPR (adopted 16 December 1948, entered into force 23 March 1976) 999 UNTS 171; ICESCR (adopted 16 December 1948, entered into force 3 January 1976) 993 UNTS 3.

87 UN Charter (adopted 26 June 1945, entered into force 24 October 1945) 3 Bevans 1153, art 1(3). 
nation norm prohibiting discrimination in the enjoyment of rights guaranteed by the instrument in question; others, such as ICCPR, IESCR and the African Charter on Human and Peoples' Rights, contain, in addition to such a norm, also a free-standing, autonomous norm proclaiming equality before the law and the right to equal protection of laws. ${ }^{88}$ ICCPR and IESCR also contain a provision guaranteeing equal rights of men and women. ${ }^{89}$ Most instruments contain an open-ended list of prohibited grounds (except for the UN Charter, IESCR, CRC) and all include sex, which has gained the status of a 'suspect classification' in international human rights law. ${ }^{90}$

Most of the instruments do not provide a definition of discrimination, except for CEDAW and CERD. It seems to have been accepted in international human rights jurisprudence that direct and indirect, intentional and non-intentional, de jure and de facto discrimination is covered. ${ }^{91}$ However, most of the international human rights cases have dealt with direct intentional discrimination only. The jurisprudence on indirect discrimination has been slow to develop. The European Court of Human Rights has been particularly restrictive on this matter. ${ }^{92}$ However, the concept of indirect discrimination is crucial for challenging systemic forms of discrimination and disadvantage as it "directs attention to myriad ways in which dominant standards and more systematic forms of discrimination in our society, which are at face value neutral, tend to disadvantage or exclude members of less powerful groups. ${ }^{93}$

As stated above, most instruments have also been silent on affirmative measures. It has generally been accepted that they are not prohibited under the non-discrimination norm as long as they have an objective and reasonable aim, are temporary and do not result in the maintenance of

\footnotetext{
88 While the ECHR contains only a subordinate non-discrimination provision in Article 14, Protocol 12 to the ECHR, which came into force on 1 April 2005, contains a free-standing non-discrimination provision. However, the provision reaches only to the 'public' sphere, by requesting that enjoyment of any right set by law be secured for anyone without discrimination and by prohibiting discrimination 'by any public authority' (emphasis added). Protocol 12 to the European Convention on Human Rights, CETS No 177.

89 The right has been interpreted in a manner aimed at substantive equality. See HRC, 'General Comment no 28' and CESCR, 'General Comment no 16' (n 19 and n 20).

90 Anne Bayefsky, 'The Principle of Equality and Non-discrimination in International Law' (1990) 11 Human Rights Law Journal 1; Aileen McColgan, 'Principles of Equality and Protection from Discrimination in International Human Rights Law' (2003) 2 European Human Rights Law Review 157.

91 Ibid.

92 See for example DH and Others $v$ Check Republic (App no 57325/00) (2006) ECHR 2006.

93 Titia Loenen and others, Non-Discrimination: Comparative Perspectives (Kluwer Law International, The Hague 1999) 199.
} 
unequal or separate standards. ${ }^{94}$ However, most of the instruments do not mandate special measures. Affirmative measures are still seen as exceptional and in need of justification, even though they 'are crucial for eradicating gender discrimination, for remedying historical disadvantages that women suffer, and accelerating the equal participation of women in the political, economic, social, cultural, civil or any other field', as recognised by the CEDAW Committee. ${ }^{95}$ They should not be seen as 'an exception to the norm of non-discrimination, but rather as ... a part of a necessary strategy by States parties directed towards the achievement of de facto or substantive equality of women with men in the enjoyment of their human rights and fundamental freedoms. ${ }^{96}$

Finally, there is confusion over whether and to what extent nondiscrimination provisions reach into the 'private sphere' - whether and to what extent the state has an obligation to eliminate discrimination and promote gender equality in the relations between private individuals. CEDAW, CERD, the African Protocol on Women's Rights and Inter-American Convention on Violence against Women clearly reach into the private sphere, and most of the human rights committees have clarified that states have obligations to take steps to eradicate discrimination against women by private individuals. ${ }^{97}$ On the other hand, the new Protocol 12 to the ECHR seems to be restricted to 'acts by public authority'. ${ }^{98}$ In addition, international human rights case law concerns primarily discrimination in the public sphere. ${ }^{99}$

The conventions are also silent on their test of equality. It has generally been accepted that non-discrimination does not always mean 'equal treatment'. ${ }^{100}$ Differential treatment that has an 'objective and reasonable' justification and where means are proportionate to that aim is not considered discriminatory. ${ }^{101}$ However, jurisprudence tends to be permissive in assessing the justification. Thus, justifications based on gender

101 While justifications generally concern state interests which are not concerned with (substantive) equality, they could, it seems, also concern interests related to pursuing substantive equality through, for example, affirmative measures.
} 
stereotypes - such as the 'fact' that at the time when the challenged legislation was passed it was customary for men to be the breadwinners have occasionally been accepted as 'reasonable and objective.' 102 The non-discrimination norm may also be breached by not providing 'different' treatment to individuals who are in a 'significantly different' situation, without 'objective and reasonable justification'. ${ }^{103}$ However, the problem is again that the assessment of the 'objectivity and reasonableness of the justification' tends to be pretty permissive. ${ }^{104}$ Moreover, is not clear whether different treatment could extend to affirmative measures. The application of all these different tests/theories often results in confusion and inconsistency.

The dominant theory of equality in international human rights law is the liberal theory of equality, based on the Aristotelian principle of treating 'likes alike and unlikes unlike'. As liberal theory sees all individuals as equals, under this theory 'equal treatment' is a norm, and 'different treatment' (especially special measures) an exception. ${ }^{105}$ However, this formula is indeterminate. No guidelines are provided for what is to be considered 'equal' and 'different' treatment (when and if it should include affirmative measures) and when individuals are to be considered 'equally' or 'differently' situated. ${ }^{106}$ As noted by Aristotle himself, the decision as to whether two individuals are alike depends on the context and measure of comparison. ${ }^{107}$

The measure of comparison (in the public sphere of law) has long been male. As women are different from men, 'equal treatment' might not promise them much except to push them into accepting male norms. The standard is not easily applicable in the areas of life where women are the least like men, both in terms of their biological and social-economic (especially power) differences. This makes the test difficult to apply to most and the worst forms of abuses that women face, such as violence against

102 HRC, 'Views on Communication no 786/1997 (Vos v. Netherlands)' (29 July 1999) UN Doc CCPR/C/66/D/786/1997.

103 ECtHR, Thlimmenos v Greece (App no 38365/97) (2000) ECHR 2000-IV.

104 In Beard $v$ UK (App no 24882/94) [GC] (2001) ECHR 2001, the Court accepted that refusal to give Roma planning permission to station residential caravans on land owned by them on account of visual impairment of site was 'objective and reasonable'.

105 See, however, Dworkin's discussion of affirmative measures. Ronald Dworkin, Taking Rights Seriously (Harvard University Press, Harvard 1997) ch 9.

106 Functional equality (in terms of the same capability to perform a certain function) is the meaning of equality most often applied in litigation, as neither material equality (in term of sameness) nor moral equality (in term of same moral worth) are helpful since no two individuals are the same, and it is generally accepted that we, as humans, all have equal moral worth. However, what constitutes 'functional' equality, and in which aspects a woman and man are alike requires interpretation, and interpretation, as applied by (privileged) members of the judiciary, is based on the dominant social norm.

107 Aristotle (trs) Politics (Penguin Books, London 1981) book 3. 
women and denial of reproductive and sexual freedoms. As MacKinnon writes, 'where the lack of similarity of women's condition to men is extreme because of sex inequality, the result is that the law of sex equality does not properly apply. ${ }^{108}$ Hence the test does not hold promise for achieving substantive equality.

On the other hand, the 'accommodation of differences' test (as applied in the still gendered system of international human rights law), while better at addressing difference than the equal treatment test, might be problematic on the same grounds: its presupposition of a norm. ${ }^{109}$ The test assesses difference and establishes the treatment such a difference should invoke in comparison to a standard. Hence, affirmative measures are conceptualised as 'special measures'. However, defining affirmative measures as special may support stereotypes and discrimination of women as different and weak, in need of special protection. In addition, 'different treatment' might help to maintain separate standards for women and men and affirm the binary conception of gender.

This is not to argue that differences between women and men should not be acknowledged; it is just to argue that focus should not be on the differences from men, it is just to argue against adopting the male standard. If substantive equality is to be achieved, the differences in power have to be taken into account, and measures have to be taken to ensure that both women and men enjoy their human rights, but there is nothing really 'special' in this claim. In addition, for many people being a woman or a man is not the most significant identity characteristic, and some cannot define themselves as either, and are often discriminated against precisely on this ground.

MacKinnon argues that the 'dominance approach' is the best suited to achieve substantive equality. Under this standard, the question to be asked is not the question of difference or sameness, but rather the question of distribution of power, of 'male supremacy and female subordination'. ${ }^{110}$ Thus, the question should not be whether there is unjustified differential treatment or unjustified non-accommodation of differences, but rather whether the law or practice at issue perpetuates or produces the subordination of women. This test does indeed seem to be better

108 CA MacKinnon, 'On Torture' in Are Women Human? (n 50) 26.

109 The difference standard has been promoted by cultural feminists, who have insisted on women's differences and celebrated them, arguing against assimilation to a male standard. However, many feminists have criticised this stance on the grounds that the 'differences' it celebrates are the product of patriarchy. See for example CA MacKinnon, Feminism Unmodified: Discourses on Life and Law (Harvard University Press, Harvard 1987); and Joan Williams 'Deconstructing Gender' in Hillary Barnett (ed) Sourcebook on Feminist Jurisprudence (Cavendish Publishing Limited, London 1997).

110 MacKinnon, ibid 40. 
suited to achieve substantive equality than the equal/different treatment test. It does not require the person to show how $\mathrm{s} / \mathrm{he}$ is the same or different from the norm in order for the equality principle to be applicable, but only how s/he suffers disadvantage and how the law or policy in question facilitates such disadvantage. Such an approach brings a wide range of problems that women and other marginalised groups face, such as violence, violations of sexual and reproductive rights, under the ambit of the equality norm. It is not limited to securing treatment according to the dominant values of unequal societies, but aims at transforming these values to include the perspective of the marginalised. However, MacKinnon's test should be modified by the critiques of the theorists of intersectionality of discrimination directed at the essentialism of MacKinnon's theories. ${ }^{111}$ Hence, in assessing disadvantage, attention should be paid to multiplicity of identities and intersectionality of discrimination, and credibility should be given to the voices of those affected.

\section{Conclusion}

This paper has shown how women's rights have long been marginalised in international human rights law. While international human rights law has recently started to acknowledge women's rights as an 'inalienable, indivisible and integral' part of universal human rights law, ${ }^{112}$ its conceptual framework remains gender biased. Feminists have identified the gendered nature of the public/private divide as the main obstacle for the protection of women's rights.

The public/private division is visible at many levels of international law: in the conceptualisation of rights, the doctrine of state responsibility and the equality norms. International human rights law is still focused on the public sphere: its main function is to guard against the totalitarian state. Hence, the types of violations of human rights that men typically suffer (in the 'public sphere' by state agents) are still much more visible than the violations that women typically suffer (in the 'private sphere' by men). The dominant interpretation of human rights in 'mainstream' international human rights law is still gender biased. Civil and political rights still do not fully acknowledge that the threats to the enjoyment of these rights by women are most often sex specific (ie that they take the form of violence against women or violations of reproductive rights); social and economic rights still do not adequately acknowledge the context

111 MacKinnon's theory gives a one-dimensional account of women's subordination and assumes the centrality of gender oppression, neglecting other systems of discrimination. For a critique, see Kimberle (n 4); Cain (n 4); Angela Harris, 'Race and Essentialism in Feminist Legal Theories' (1990) 42 Stanford Law Review 581.

112 Vienna Declaration and Programme for Action (n 8). 
of women's social and economic disadvantage; and collective rights fail to acknowledge the context of gender discrimination within the communities they aim to empower.

Moreover, the norms of state responsibility are still applied narrowly in respect of violations of the human rights of women. Despite the widespread and systemic nature of violence against women, states have rarely been held responsible in the absence of direct state action (or omission to redress through legal means). In addition, obligations are primarily imposed in the 'public sphere' of law and the states are given wide discretion in respect of the implementation of positive obligations, in particular when they touch upon the 'private sphere' of cultural and moral norms. Finally, the principle of (sex) equality has been conceptualised in a narrow manner. The dominant test of equality is equal treatment (in the public sphere). Exceptionally, different treatment might be required when individuals are in a significantly different situation. However, it is not clear whether affirmative measures would be mandated (and if so, when) under this approach. The main concern is with the equality of treatment, rather than the result.

These discussions suggest that international human rights law needs to be re-conceptualised so as to fully include women's experiences of human rights abuse and thus becomes more inclusive and truly universal. If women's rights are to be effectively protected, the gendered nature of the public/private divide needs to be transcended. The dichotomy should be re-conceptualised in a manner that challenges discrimination and violence against women in the private sphere, while protecting the freedom to self-determination and personal development in both 'public' and 'private' spheres. It is only then that the freedom of all people can be protected.

Re-conceptualising the public/private divide in a manner that incorporates the experiences of women would require using gender analysis in interpreting rights, state responsibility and equality. Gender analysis would reveal the context of violence against women and their social, economic and cultural disadvantage. This should result in incorporating violence against women and reproductive rights in the interpretation of all three generations of rights and the re-conceptualisation of collective rights in a manner that promotes the self-determination of women. Moreover, the responsibility of the state for maintaining the system of gender discrimination should be acknowledged. Hence, the state should have positive obligations to challenge women's disadvantage. The state responsibility for violations of human rights in the 'private sphere' needs to be clearly acknowledged. The obligations should not be limited to the 'public sphere' of law and administration, but also to the 'private sphere' of cultural and social norms, since, without addressing them, patriar- 
chy cannot be eradicated. Finally, gender analysis would reveal that the equal/different treatment approach to equality is not meaningful to women as it cannot challenge their structural disadvantage. Therefore, equality should be re-conceptualised as challenging disadvantage. Under this approach, the relevant question would be whether the challenged measure produces or maintains (multiple and intersectional forms of) the disadvantage of traditionally disadvantaged groups. 